relationship between cow size and efficiency. This is illustrated by work in Texas (R. C. Thomas, personal communication) where the $320 \mathrm{~kg}$ Angus $\times$ Jersey cow mated with the Charolais required $12 \cdot 8 \%$ less feed for each $\mathrm{kg}$ of calf weaning weight than the $480 \mathrm{~kg}$ pure-bred Hereford and $9.5 \%$ less than the $550 \mathrm{~kg}$ pure-bred Charolais. For each $\mathrm{kg}$ of yearling weight the cross-bred Angus cow required $7 \%$ less feed than the Hereford and $5.6 \%$ less feed than the Charolais. More information of this type will be derived from experiments in North America but it seems unlikely that such detailed work will be repeated in Britain because of the large-scale facilities required. Because of variations of the ability of cows to forage and of suitability of herd social structures to the environment, results collected under carefully controlled experimental conditions may fail to give a complete answer.

With cows of a given body size efficiency can be radically improved if the growth potential of calves can be improved. The obvious approach is to cross hardy hill cows with breeds of higher growth potential but in practice the scope for crossbreeding may be limited by the need to breed a large proportion of the herd pure to ensure the replenishment of hill stocks.

\title{
REFERENCES
}

Hemingway, R. G. (1971). Proc. Nutr. Soc. 30, 22I.

Hight, G. K. (1968a). N.Z. fl agric. Res. I1, 71 .

Hight, G. K. (1968b). N.Z. $\mathscr{~ l l ~ a g r i c . ~ R e s . ~ I I , ~} 477$.

Lamond, D. R. (1970). Anim. Breed. Abstr. 38, 359.

Wiltbank, J. N. (1970), J. Anim. Sci., 31, 755.

\section{Physiological factors affecting the energy cost of cold exposures}

\author{
By J. SLeE, Agricultural Research Council, \\ Animal Breeding Research Organisation, Edinburgh EH9 $39 Q$
}

The immediate physiological consequences of cold exposure are well known. Sheep and cattle, the farm animals most commonly exposed to cold, display a variety of responses typical of homoeotherms. Apart from behavioural and postural adjustments, these include, first, piloerection, vasoconstriction and lowered respiratory rate; and secondly, shivering coupled with increases in heart rate, respiratory tidal volume and metabolic rate. The earlier responses reduce heat loss to the environment and are, therefore, energy-sparing. The other responses involve an increased energy demand. The ambient temperature below which heat production first increases is termed the lower critical temperature. The critical temperature is affected by the animal's physical insulation, which in turn is influenced by the morphology of the skin and the coat. Armstrong, Blaxter, Clapperton, Graham \& Wainman (1960) for sheep, and Blaxter (1964a) for sheep and cattle have discussed the relationships between coat length, insulation and the critical temperature, and assessed heat exchanges between the animal and the environment. Blaxter ( $1964 b)$ and Joyce \& Blaxter (1964) have shown how these relationships can be altered by the level of 
nutrition and also by wind and rain, which break down coat insulation and increase the cooling power of the environment. When the ambient temperature becomes subcritical the initial physiological responses such as vasoconstriction occur within a few minutes in sheep (Webster \& Blaxter, 1966; Slee, 1966, 1968). The metabolic response also commences quickly but may take between $3^{\circ}$ min and $3 \mathrm{~h}$ to reach equilibrium (Joyce \& Blaxter, 1964; Webster, 1966).

These energy costs of cold exposure must eventually be reflected in live-weight loss or increased food intake. Live-weight changes in sheep following natural exposure have been determined by Armstrong, Blaxter, Graham \& Wainman (1959), Doney (1963) and Winfield, Brown \& Lucas (1968). The average weight loss attributable to wintering outdoors varied in different experiments from nil to about $5 \mathrm{~kg}$. The variation depended on the breeds used, the severity of the winters and the level of nutrition.

Other experiments recorded the energy demand of natural winter environments in terms of food requirement rather than weight loss. Generally, two main methods of comparison between outdoor and housed sheep were used: (x) measurement of voluntary food intakes, (2) measurement of the intakes required to maintain live weight, or to maintain specific levels of serum free fatty acids (FFA) in the blood. Serum FFA provides an index of the rate of mobilization of body fat and indicates the extent to which energy demand exceeds that available from the current nutrient intake. One experiment of the first type suggested that food intakes were increased by $20 \%$ by exposing sheep to an outdoor winter environment (Winfield et al. 1968). Wodzicka-Tomaszewska (1963), in another experiment, found an increased drymatter intake of $50 \%$ over a period of 3 months after shearing. In the short term, however, the effects of cold exposure are less clear. Webster \& Lynch (1966) found that food intakes of sheep exposed to cold weather after shearing may decrease at first. Sykes \& Slee ( $1969 a$ ) likewise reported a higher incidence of food refusal among shorn sheep exposed to a cold environment in climatic chambers than among those kept warm. Again, Slee and Wiener (unpublished) found that food consumption decreased by about $12 \%$ during the week following severe cold stress of young rams.

Apparently, while food consumption generally increases during long-term cold exposure, the immediate response to cold is variable. Temporarily decreased intakes, perhaps associated with discomfort and stress, are common.

Using the other means of comparison, Doney \& Russel (1968) measured the maintenance requirements of different breeds of sheep penned outdoors, and Russel \& Doney (I969) monitored FFA levels to determine nutrient requirements-again between breeds in the same natural environment. Making use of controlled artificial environments, however, Slee \& Halliday (1968) examined FFA levels in sheep exposed to different intensities of cold in climatic chambers. In maintenance-fed animals chronic mild cold exposure at $8^{\circ}$ below the critical temperature elicited small elevations in FFA of about $15^{\circ} \mu$ equiv. $/ 1$ blood serum. The effect was maximal about $\mathrm{I} 5 \mathrm{~h}$ after feeding. Other experiments (Halliday, Sykes, Slee, Field \& Russel, 1969) showed that moderate cold exposure ( $20^{\circ}$ subcritical) produced elevations of 300-600 $\mu$ equiv. $/ 1$, depending upon the level of feeding. Very severe exposures of shorn 
sheep for $3^{-8 \mathrm{~h}}$ at $-20^{\circ}$ with $6.4 \mathrm{~km} / \mathrm{h}$ wind (effectively over $60^{\circ}$ subcritical) yielded FFA elevations of 2000-3000 $\mu$ equiv./1. These values were sustained for several hours even after the onset of hypothermia. Although circulating FFA are the main fuel for heat production during acute cold stress, there is no evidence that hypothermia necessarily results from failure of mobilization or depletion of fat.

Among the most comprehensive investigations concerning the physiological effects of climatic stress were those of Alexander (e.g. 1961, I 962a,b,c, I964). Working in Australia with newborn Merino lambs, Alexander identified the major factors determining survival. These were: previous maternal nutrition and resultant energy reserves in the lamb, behaviour and earliness of suckling, birth weight, birth-coat insulation, summit metabolic capability and weather. Large lambs with good nutritional reserves and long birth-coats had the best chance of survival. Extrapolation from laboratory trials suggested that such lambs could maintain homoeothermy for some hours at an ambient temperature of about $-35^{\circ}$ even in wet weather. Correspondingly, undersized lambs with fine birth-coats would be unable to generate enough heat at temperatures below about $+13^{\circ}$. In lambs from adequately fed ewes, energy reserves at birth averaged over $250 \mathrm{kcal} / \mathrm{kg}$-of which about $170 \mathrm{kcal}$ were obtainable from fat, and $40 \mathrm{kcal}$ each from glycogen and protein. In lambs from poorly fed ewes, reserves totalled about $130 \mathrm{kcal} / \mathrm{kg}$, the decline being mainly due to a reduction in fat. Normal lambs could develop a summit metabolic rate of about $\mathrm{I} 7 \mathrm{kcal} / \mathrm{kg}$ per $\mathrm{h}$ within $30 \mathrm{~min}$ of birth, but lambs from poorly fed ewes were slower to reach peak metabolism. Such high metabolic rates could probably not be maintained for longer than a few hours and in some instances energy supplies were a limiting factor. Metabolic rates tended to be higher and sustained longer after suckling. However, even among starved lambs, depending upon their nutritional reserves, their physical insulation and the prevailing weather conditions, theoretical survival times varied from $12 \mathrm{~h}$ to $5 \mathrm{~d}$.

Clearly, the survival of newborn lambs in cold weather depends considerably upon the available fat stores. Newborn mammals in general vary considerably in their ability to raise heat production in response to cold and in their dependence for this upon brown or white adipose tissue (Hull \& Hardman, 1970). The human infant is poorly insulated, but has large stores of brown fat and can increase heat production by non-shivering thermogenesis (NST). Piglets have poor insulation also, but they shiver and probably have little or no brown fat (Mount, 1968). Calves also have no brown fat and depend upon shivering (Jenkinson, Noble \& Thompson, 1968). Neonatal lambs are comparatively well-insulated, possess white and brown fat depots and are capable of both shivering and NST (Alexander \& Williams, , 968). Shivering is a less economical process than NST since the sites of thermogenesis are superficial and heat is readily lost by convection. Although both forms of heat production occur at birth the importance of NST declines with age. Brown fat may be exhausted within $24-36 \mathrm{~h}$ of birth, the precise period perhaps depending upon the severity of cold experienced. Depletion of brown fat in response to cold exposure may not represent an energy cost of exposure, in that this material is always available at birth and is probably not replaced afterwards. However, other energy sources - white fat and 
glycogen-become, soon after birth, the main substrates for heat production (Alexander \& Williams, I 968) and these energy stores normally have to be replenished.

Although the effects of cold exposure upon heat loss and long-term energy requirements are well established, the impact of physiological adaptations to cold - such as acclimatization - has been relatively neglected in farm livestock. Acclimatization to cold has long been recognized in laboratory animals (Gelineo, 1934; Hart, 1957), but was less generally accepted in man (Adolph \& Molnar, 1946; Horvath, Freedman \& Golden, I947). Later, however, Davis (I961) and Budd (1965) reported different types of human acclimatization. The divergent results may be accounted for by differences of methodology and definition. Even now, almost 40 years after Gelineo's experiments, there is no generally agreed criterion defining the state of acclimatization. However, the physiological changes may include: increased resting metabolic rate (RMR), increased metabolic capability in response to cold, greater reliance upon NST, elevated skin temperature, increased resistance to cooling and improved survival at low temperatures. Most of these changes imply increases in energy consumption and heat loss. In contrast, Davis (I963) showed that seasonal acclimatization in man could involve reduced heat production and lowered body temperature. Such energy-saving responses parallel those of the Australian Aborigine and African Bushman during natural cold exposure, and contrast with those of the Eskimo or unacclimatized European who require increased metabolism (Hammel, I964).

A distinction is often made between natural acclimatization in the field, involving exposure to a variety of fluctuating stimuli including light, temperature, nutrition, wind and rain; and laboratory acclimatization caused by exposure to controlled doses of cold with other variables held constant. Natural seasonal acclimatization may involve energy-sparing adaptations like the improved coat insulation of some arctic mammals (Scholander, Hock, Walters, Johnson \& Irving, I950; Irving, Krog \& Monson, 1955), or increased metabolic activity as in the wild deer mouse and other small mammals (Hart, 1957).

It is clearly useful to consider what forms of adaptation to cold can occur in farm livestock and whether these are energy-consuming or energy-sparing. The work of Slee \& Sykes $(1967)$ and Sykes \& Slee $(1968,1969 a, b)$ indicates that laboratory acclimatization can be induced in shorn sheep by exposure to acute cold stress $\left(-20^{\circ}\right.$, $6.4 \mathrm{~km} / \mathrm{h}$ wind) for several hours and by exposure to moderate cold $\left(+8^{\circ}\right)$ for 2 weeks. Various combinations of these treatments caused : increased resistance to body cooling; increased heart rates during mild cooling and at thermoneutral temperatures; increased skin temperatures, especially on the extremities; delayed peripheral vasoconstriction during cooling. It was inferred that increased cold resistance was attributable to greater summit metabolic capability, whereas the changes in heart rate and skin temperature were associated with an elevated RMR. It has also been found (Slee, unpublished) that, in the absence of further cold stimulus, the improvement in cold resistance persists for about 6 weeks, whereas the changes associated with increased RMR only last about $8 \mathrm{~d}$. The latter responses, although short-lived in the absence of cold stress, presumably involve an energy cost. 
Without direct measurements of metabolic rate, crude estimates of energy-cost can be made by reference to changes in heart rate. There is some controversy as to the relationship between heart rate and metabolic rate. Graham (1960-6I) observed in sheep a correlation between changes in heart rate and metabolic rate and Webster ( 1967 ) found a good association in certain individual sheep. Brockway \& McEwan (I969), on the other hand, found a good correlation in only one out of five sheep. However, these heart rates were high, indicating the possibility of emotional disturbance, although the range over which the rates altered was fairly small. From our experience in this laboratory, heart rate may relate to metabolic rate if: the animals are in a controlled environment and not subject to emotional disturbance; the heart rates are derived from the average responses of groups of animals rather than from individuals; the heart rates are used to determine when metabolic rates change, and whether up or down, rather than to estimate absolute values for metabolic rate.

Our experiments involve observations, in climate chambers, on over roo shorn sheep before and after acclimatization to cold. Average heart rates at thermoneutral ambient temperatures were increased by 20 beats $/ \mathrm{min}$ after acclimatization. Using the relationships between heart rate and metabolic rate calculated by Webster ( 1967 ) for his two sheep with the best fit, we find that a heart rate difference of 20 beats $/ \mathrm{min}$ is equivalent to a difference in metabolic rate of about $25 \mathrm{kcal} / \mathrm{h}(600 \mathrm{kcal} / 24 \mathrm{~h}$ ). Assuming the thermoneutral RMR of an unacclimatized adult sheep to be about $2000 \mathrm{kcal} / 24 \mathrm{~h}$ (Armstrong et al. I959), this represents an increase of $30 \%$. Alternatively, this increase is equivalent to half the expected daily energy retention of a 60 $\mathrm{kg}$ sheep on high-level feeding (Wainman, Blaxter \& Pullar, 1970). However, without further cold exposure the elevated RMR would be expected to disappear within $8 \mathrm{~d}$. Moreover, during moderate cold exposure, the difference in metabolic rate between acclimatized and non-acclimatized sheep is probably reduced, since the latter raise their heat production earlier in response to the cold stimulus.

Cold-acclimatized sheep also have elevated skin temperatures. Results from Sykes $\&$ Slee $\left(1968,1_{96} 6 b\right)$ indicate a weighted mean whole body skin temperature increase of about $I^{\circ}$. Using the equation,

$$
\mathrm{H}=\frac{\mathrm{T}_{\mathrm{s}}-\mathrm{T}_{\mathrm{A}}}{\mathrm{I}}
$$

where $H$ is the heat flow from the skin surface, $T_{S}$ is the skin temperature, $T_{A}$ is the air temperature and $I$ is the insulation due to the skin-air interface $+5 \mathrm{~mm}$ wool (from Blaxter, 1962), the difference in heat loss resulting from a difference of $I^{\circ}$ in temperature gradient was estimated to be about $15 \%$. The fact that acclimatization apparently produced a greater increase in heat production than heat loss may be accounted for by heat storage, since the rectal temperatures of acclimatized sheep were frequently elevated (Slee \& Sykes, I967).

Other experiments involving long-term adaptation to cold have been reported by Webster, Hicks \& Hays (I 969), who used unshorn sheep exposed either outdoors or in refrigerated rooms. The latter showed the characteristic features of acclimatization to cold, including increased resistance to body cooling under acute cold stress, 
increased summit metabolism and increased RMR. The elevation in RMR reached a maximum of $17 \%$. These indoor-acclimatized sheep ate about $12 \%$ more food than either unexposed controls or the sheep kept outdoors. This presumably resulted not just from cold exposure but from the extra energy cost of acclimatization, since both the indoor and outdoor sheep received similar dosages of cold. The responses of the outdoor sheep, which had been exposed to the fluctuating but extreme temperature stress of the Canadian (Alberta) winter, were also of considerable interest. RMR in these sheep increased less rapidly than in those cold-exposed indoors; they also showed a smaller metabolic response to severe cold, but equally good resistance to body cooling. In some respects this form of adaptation was similar to that produced by exposing sheep to short, daily cold shocks in climate chambers (Slee, 1970, and unpublished). Here there was a reduced metabolic response to cold and consequently lower body temperatures. Both this treatment and the outdoor environment in Canada tended to reduce the energy-cost of cold exposure. These adaptations resemble the phenomenon of habituation (Glaser, 1966; Hensel \& Hildebrandt, 1964) which involves a diminished physiological response to a repeated stimulus.

Apparently, cold adaptation in sheep may take different forms as a result of laboratory or field acclimatization, or habituation-each probably involving differences in energy expenditure. There is as yet no clear evidence in adult sheep for the development of NST, which is perhaps the most efficient means of heat production. Sykes \& Slee ( 1968 ) did suspect decreased shivering intensity after acclimatization in Blackface sheep, but not in other breeds. Which type of adaptation occurs may depend upon the mode of administration and dosage of cold, and upon a genetic predisposition towards one response or another. Current experiments at this laboratory may clarify these questions and perhaps lead to some understanding of their implications for the efficiency of energy utilization.

Finally, if these forms of cold adaptation differ in their energy demands, they may also differ in their effectiveness for specific situations. For a deserted newborn lamb subject to long-term cold stress, or for a hill-sheep exposed to prolonged cold stress and under-nutrition, energy-sparing adaptation would seem desirable. However, for newly shorn sheep, or newborn lambs with an assured milk supply but subjected to a short cold stress, increased energy expenditure might be acceptable if it permitted warmer extremities, greater comfort and mobility and consequent preservation of the drive to feed or suck. How far natural processes of cold adaptation fit the requirements of farm livestock in any given situation is a complex question to which there are, as yet, few answers.

\section{REFERENCES}

Adolph, E. F. \& Molnar, G. W. (1946). Am. F. Physiol. 146, 507.

Alexander, G. (1961). Aust. F. agric, Res, 12, 152.

Alexander, G. (1962a). Aust. $¥$. agric. Res. $\mathrm{x}_{3}, 82$.

Alexander, G. (1962b). Aust. F. agric. Res. 13, 100.

Alexander, G. (1962c). Aust. F. agric. Res. 13, 122.

Alexander, G. (1964). Proc. Aust. Soc. Anim. Prod. 5, I 3.

Alexander, G. \& Williams, D. (1968). J. Physiol., Lond. 198, 25 I.

Armstrong, D. G., Blaxter, K. L., Clapperton, J. L., Graham, N. McC. \& Wainman, F. W. (I960) F. agric. Sci., Camb. 55, 395. 
Armstrong, D. G., Blaxter, K. L., Graham, N. McC. \& Wainman, F. W. (1959). Anim. Prod. x, I. Blaxter, K. L. (1962). The Energy Metabolism of Ruminants. London: Hutchinson.

Blaxter, K. L. (1964a). Vet. Rec. 76, 1445.

Blaxter, K. L. (1964b). Proc. int. Congr. Nutr. vi Edinburgh, 1963, p. 227. Edinburgh and London: E. and S. Livingstone Ltd.

Brockway, J. M. \& McEwan, E. H. (1969). J. Physiol., Lond., 202, 66r.

Budd, G. M. (1965). F. appl. Physiol. 20, 417.

Davis, T. R. A. (196r). F. appl. Physiol. 16, ror 1.

Davis, T. R. A. (1963). In Temperature, its Measurement and Control in Science and Industry Part III. Biology and Medicine p. 433. [J. D. Hardy, editor]. New York: Reinhold.

Doney, J. M. (1963). F. agric. Sci., Camb. 60, 267.

Doney, J. M. \& Russel, A. J. F. (1968). F. agric. Sci., Camb. 71, 343.

Gelineo, M. S. (1934). Annls Physiol. Phisicochim. biol. 10, 1083.

Glaser, E. M. (1966). The Physiological Basis of Habituation. London: Oxford University Press.

Graham, N. McC. (1960-6r). C.S.I.R.O. Anim. Res. Labs. A. Rep. p. 94.

Halliday, R., Sykes, A. R., Slee, J., Field, A. C. \& Russel, A. J. F. (1969). Anim. Prod. x1, 479.

Hammel, H. T. (1964). In Handbook of Physiology, Sect. 4. Adaptation to the Environment p. 413. [D. B. Dill, editor]. Baltimore: American Physiological Society.

Hart, J. S. (I957). Rev. can. Biol. 16, 133 .

Hensel, H. \& Hildebrandt, G. (1964). In Handbook of Physiology. Sect. 4. Adaptation to the Environment p. 55 [D. B. Dill, editor]. Baltimore: American Physiological Society.

Horvath, S. M., Freedman, A. \& Golden, H. (1947). Am. F. Physiol. r5o, 99.

Hull, D. \& Hardman, M. J. (1970). In Brown Adipose Tissue p. 97 [O. Lindberg, editor]. New York: Elsevier Publishing Co.

Irving, L., Krog, H. \& Monson, M. (1955). Physiol. Zoöl. 28, x73.

Jenkinson, D. M., Noble, R. C. \& Thompson, G. E. (I 968). F. Physiol., Lond. 195, 639.

Joyce, J. P. \& Blaxter, K. L. (1964). Br. F. Nutr. 18, 5.

Mount, L. E. (1968). The Climatic Physiology of the Pig, London: Arnold.

Russel, A. J. F. \& Doney, J. M. (1969). F. agric. Sci., Camb. 72, 59.

Scholander, P. F., Hock, R., Walters, V., Johnson, F. \& Irving, L. (1950). Biol. Bull. 99, 237.

Slee, J. ( ( 966). Anim. Prod. 8, 425.

Slee, J. (1968). Anim. Prod. 10, 265.

Slee, J. (1970). Anim. Prod. 12, 13.

Slee, J. \& Halliday, R. (1968). Anim. Prod. Io, 67 .

Slee, J. \& Sykes, A. R. (1967). Anim. Prod. 9, 333.

Sykes, A. R. \& Slee, J. (I968). Anim. Prod. ro, I7.

Sykes, A. R. \& Slee, J. (1969a). Anim. Prod. 11, 65.

Sykes, A. R. \& Slee, J. (I $969 b)$. Anim. Prod. II, 77.

Wainman, F. W., Blaxter, K. L. \& Pullar, J. D. (1970). F. agric. Sci., Camb. 74, 31 I.

Webster, A. J. F. (1966). Res. vet. Sci. 7, 454.

Webster, A. J. F. (1967). Br. F. Nutr. 2r, 769 .

Webster, A. J. F. \& Blaxter, K. L. (1966). Res. vet. Sci. 7, 466.

Webster, A. J. F., Hicks, A. M. \& Hays, F. L. (1969). Can. F. Physiol. Pharmacol. 47, 553.

Webster, M. E. D. \& Lynch, J. J. (1966). Proc. Aust. Soc. Anim. Prod. 6, 195.

Winfield, C. J., Brown, W., \& Lucas I. A. M. (1968). Anim. Prod. ro, 45 I.

Wodzicka-Tomaszewska, M. (1 g63). N.Z. Yl agric. Res. 6, 440 .

\section{Minerals in the nutrition of hill cattle and sheep}

\section{By R. G. Hemingway, Glasgow University Veterinary School, Bearsden, Glasgow}

In systems of animal production which are dependent upon the natural vegetation, as applies with hill cattle and sheep, it is clearly important to establish the pattern of potential mineral intake based on studies of plant composition. Such investigations are subject to major sources of error. Most hill farms are large and cover wide ranges of elevation, drainage and types of soil parent-material. A single farm may embrace 